\title{
The Islamic Law of Marriage and Inheritance in Kenya
}

\author{
Jamil Ddamulira Mujuzi* (1) \\ University of the Western Cape, Bellville, South Africa \\ E-mail: jdmujuzi@uwc.ac.za
}

\begin{abstract}
Article 24(4) of the Constitution of Kenya qualifies the right to equality "to the extent strictly necessary for the application of" Islamic law "in matters relating to personal status, marriage, divorce and inheritance". Section 3 of the Marriage Act provides that, although spouses have equal rights during marriage and at its dissolution, "the parties to an Islamic marriage shall only have the rights granted under Islamic law". The Law of Succession Act states that it is generally not applicable to the estate of a deceased Muslim. In this article, the author examines case law from the Kadhi's Court, the High Court and the Court of Appeal on issues of Muslim marriages and inheritance. These cases illustrate, in some instances, the tensions between Islamic law and human rights.
\end{abstract}

\section{Key words}

Kenya, Islamic law, Muslim law, sharia, marriage, inheritance, Kadhi's courts, freedom of testation

\section{INTRODUCTION}

Article 24(4) of the Constitution of Kenya (2010) provides that the Bill of Rights, and in particular the right to equality, "shall be qualified to the extent strictly necessary for the application of Muslim law before the Kadhis' courts, to persons who profess the Muslim religion, in matters relating to personal status, marriage, divorce and inheritance". Hence section 3 of the Marriage Act ${ }^{1}$ provides that:

"(1) Marriage is the voluntary union of a man and a woman whether in a monogamous or polygamous union and registered in accordance with this Act. (2) Parties to a marriage have equal rights and obligations at the time of the marriage, during the marriage and at the dissolution of the marriage. (3) All 
marriages registered under this Act have the same legal status. (4) Subject to sub-section (2), the parties to an Islamic marriage shall only have the rights granted under Islamic law."

The Marriage Act accommodates Islamic law relating to marriage and divorce. Thus section 49(3) of the Act provides that "[a]ny provision of this Act which is inconsistent with Islamic law and practices shall not apply to persons who profess the Islamic faith." Under the Islamic law of inheritance, as a general rule, a woman's share is half of that of a man, children born out of wedlock and non-Muslims do not inherit from their father or from any Muslim respectively. Case law from Kenyan courts, including the Khadi's Court, shows that these rules have raised some human rights issues, especially the right to equality, property and freedom of testation.

The discussion also shows that Islamic law is of the same legal force as Kenyan legislation on marriage and inheritance. However, it, as with any other law in Kenya, has to be applied in a manner that is consistent with the Constitution. The purpose of this article is to assess this jurisprudence on the issues of marriage and inheritance and highlight some of the contentious issues dealt with by the courts. It is argued that the Court of Appeal's decision in CKC \& another (Suing through their mother and next friend JWN) $v$ $A N C,{ }^{2}$ in which it held that a child born out wedlock could inherit from his/her Muslim father, is questionable, and that although a Muslim has freedom of testation, his/her will has to comply with Islamic law for it to be valid. The author will first discuss the jurisprudence from Kenyan courts on the issue of Islamic marriages before discussing the jurisprudence on inheritance. This is important because many of the cases on inheritance arise from the legality or otherwise of a marriage. Before discussing the jurisprudence emanating from Kenyan courts on the issues of Muslim marriages and inheritance, the author will briefly deal with the jurisdiction of Kadhi's Courts.

\section{JURISDICTION OF THE KADHI'S COURT}

Article $170(1)$ of the Constitution establishes the Kadhi's courts. ${ }^{3}$ A Kadhi's Court is one of the subordinate courts ${ }^{4}$ and is supervised by the High Court. ${ }^{5}$ Article $170(5)$ provides that "[t]he jurisdiction of a Kadhi's court shall be limited to the determination of questions of Muslim law relating to personal status, marriage, divorce or inheritance in proceedings in which all the parties profess the Muslim religion and submit to the jurisdiction of the

2 CKC \& another (Suing through their mother and next friend JWN) $v$ ANC [2019] eKLR.

3 For the challenge to the constitutionality of the Khadi's courts, see Jesse Kamau $\& 25$ Others v Attorney General [2010] eKLR.

4 Art 169(1) of the Constitution.

5 Art 165(6). 
Kadhi's courts." ${ }^{6}$ Section 5 of the Kadhis' Courts Act ${ }^{7}$ reproduces article 170(5) of the Constitution verbatim. In $\mathrm{HA} v \mathrm{AH},{ }^{8}$ the High Court referred to article $170(5)$ of the Constitution and held that "[t]he 3 factors on jurisdiction of the Kadhi's Court are not disjunctive but conjunctive. They must all exist together for the Court to have jurisdiction. Where they do not, the Kadhi's Court is stripped of jurisdiction." ${ }^{9}$ It is therefore a pre-condition that both parties agree that the matter should be referred to the Kadhi's Court ${ }^{10}$ and that they must be Muslims. ${ }^{11}$

For the Kadhi's Court to exercise jurisdiction in issues of marriage, the parties must "profess the Muslim religion". Courts have understood this phrase to mean that the parties are Muslim. This raises the question of whether the Kadhi's Court has jurisdiction in cases in which a Muslim man has married a non-Muslim woman. In Ramadhan Mustafa $v$ Zulfa Ngasia Juma, ${ }^{12}$ the High Court held that:

"Quran, chapter 2 Al-Baqara verse 221, there is spelt out prohibition of marriage between Muslims and persons of other religious faiths, the exception however allows Muslim men to marry women of the beliefs i.e. Jews and Christians as provided under chapter 5 verse $5 .{ }^{\prime 13}$

The Court of Appeal held that a Muslim woman is completely prohibited from marrying a non-Muslim man. ${ }^{14}$ Since many High Court judges are not experts in Islamic law, they sometimes seek the advice of legal experts (assessors), especially Kadhis, when dealing with appeals from Kadhis' courts. ${ }^{15}$ In some cases, the High Court has agreed with the expert's view, ${ }^{16}$ but in others it has disagreed with the expert. ${ }^{17}$ There are also cases in which it has agreed with

6 For a discussion of the jurisdiction of the Kadhi's Court in maintenance and custody issues, see JD Mujuzi “Contentious jurisdiction: The Kenyan Kadhis' Courts and their application of the Islamic law of custody and maintenance of wives and children" (2020) 7(1) Journal of Comparative Law in Africa 93.

$7 \quad$ Cap 11.

8 HA $v$ AH [2019] eKLR.

9 Id, para 3.

10 SKHS $v$ SSNS [2019] eKLR (Court of Appeal).

11 In Stephen Boru Elisha v Habiba Mohamed Said \& 2 others [2019] eKLR (the High Court held that the Kadhi's Court has no jurisdiction over a succession matter if the deceased was a Christian).

12 Ramadhan Mustafa $v$ Zulfa Ngasia Juma [2019] eKLR.

13 Id, para 43.

14 Sakina Sote Kaittany \& another $v$ Mary Wamaitha [1995] eKLR at 22.

15 Mako Yassin $v$ Hribaye Nane Shege $\mathcal{E} 2$ others [2018] eKLR at 3 (on the issue of Islamic law on inheritance); FBI $v$ BG [2018] eKLR (marriage law).

16 See, for example, KNM $v$ MHM [2019] eKLR, para 26 (on the issue of whether a wife has a right to be heard before the husband pronounces a talak).

17 For example, Mohamed Athman Kombo v Maua Mohamed [2019] eKLR, para 16; Fadhiya Salim Faraj $v$ Faiz Mohamoud Abdalla [2019] eKLR, para 33 (both cases on distribution of the deceased's estate); HA $v$ AH, above at note 8, para 21 (ownership of property). 
the experts' views on one of the issues yet disagreed with them on other issues. ${ }^{18}$ The fact the judges sometimes disagree with the views of Kadhis could be explained by the fact that in Kenyan law of evidence, judges are not bound by views of expert witnesses and of assessors. ${ }^{19}$

Although the High Court and the Magistrates' Court have jurisdiction to distribute the estate of deceased Muslims, there are cases in which the High Court has referred the matter(s) to the Kadhi's Court to distribute the same. ${ }^{20}$ This is because the Kadhis, in view of their expertise in Islamic law, are in a better position to distribute such estate in accordance with Islamic law. ${ }^{21}$ Even if both parties would have preferred the Kadhi's Court to distribute the estate, the High Court will nevertheless distribute it if it is in the interests of justice to do so. ${ }^{22}$ Where relatives are unable to distribute the estate of the deceased, the Kadhi's Court will assist in distributing the estate. ${ }^{23}$ The standard of proof before a Kadhi's Court is on a balance of probabilities. ${ }^{24}$ The author will now discuss the jurisprudence emanating from Kenyan courts on the issue of Islamic marriages.

\section{KENYAN COURTS AND THEIR UNDERSTANDING OF THE NATURE OF AN ISLAMIC MARRIAGE}

Section 6(1) of the Marriage Act provides that a marriage celebrated "in accordance with Islamic law" may be registered under the Act. Section 6(3) provides that "[a] marriage celebrated under ... Islamic law is presumed to be polygamous or potentially polygamous." The High Court held that "Muslims [sic] marriage like the English marriage is a contract but it is a special contract involving, as it does, strong interpersonal relationship between the bride and the bridegroom. It is not an economic transaction." ${ }^{5}$ Kenyan courts have dealt with the question of the validity of a Muslim marriage. This is important before a marriage can be registered. The discussion that follows deals with issues that courts have highlighted which relate to the validity of a Muslim marriage. In SMK $v$ RHH, ${ }^{26}$ the Kadhi's Court held that:

18 For example, in MI $v$ AA [2018] eKLR, para 25.

19 SYT $v$ TA [2019] eKLR at 2-3. On the issue of expert witnesses generally, see Apex Security Services Limited v Joel Atuti Nyaruri [2018] eKLR.

20 See for example, In re Estate of Mwangi Suleiman Kahiu (Deceased) [2019] eKLR; Mohammed Ramadhan Njoka $v$ Zainabu Wambeti Ramadhan Njoka $\mathcal{E}$ another [2006] eKLR.

21 Ashraf Abdu Kassim v Karar Omar $\mathcal{\sigma} 3$ others [2014] eKLR at 2 (case transferred from the High Court); In re Estate of Ali Ngatu (Deceased) [2018] eKLR, para 12 (case transferred from the Magistrates' Court).

22 In Re Estate of Miriam Jemutai Sang - Deceased [2011] eKLR at 1.

23 Of the many cases, see, for example, Mwanamsham Salim v Samya Said Mbarak [2015] eKLR.

24 FBI $v$ BG, above at note 15 , para 25.

25 Farhana D/O Zafarullah Kahn And Another v Mohammed Shafiq Qureshi [1997] eKLR at 4. See also, RMM v M a.k.a. JKM [2019] eKLR, para 46. SMK $v$ RHH [2015] eKLR. 
"Marriage under Islamic law is classified as: (1) valid, (2) void, and (3) irregular. According to [an] eminent Jurist, the classification is as follows: (a) lawful - that is, a marriage which is contracted in compliance with all legal requirements; (b) unlawful - that is, a marriage which has been solemnized in violation of one or another legal requirement; (c) void - that is, a marriage which, though claimed to have been solemnized, has no legal recognition at all; and (d) irregular - that is, a marriage which is unlawful but not void." ${ }^{27}$

In the above statement, the court explains the types of Islamic marriages. The Court also explains these types of marriages in detail and the rights, if any, of parties in each of these types of marriage. ${ }^{28}$ The Court held that "void marriage is no marriage at all" and "does not create any civil rights or obligations between the parties". ${ }^{29}$ However, "an irregular marriage is null and void unless the legal impediments are removed". ${ }^{30}$ Kenyan legislation does not provide for the rights of the parties in a Muslim marriage. Hence the High Court held that:

"The legislation on Mohammedan [Muslim] marriages does not contain any substantive provisions on the rights of the parties with respect to [those marriages]. These rights are governed by the Koran and the legal rules applicable to the particular sect to which the parties belong. The courts depend on Islamic scholars and Islamic scholastic works on the content of Islamic marriages." ${ }^{31}$

Thus, the starting point when one is dealing with the rights of parties to a Muslim marriage is the Quran. After that, a court will refer to the rules of the relevant Islamic sect. Therefore, the rights of parties in a Muslim marriage partly depend on the rules of a particular sect. The Kadhi's Court has explained some of these rights. For example, it held that "[t]he sharia has given a right to the husband to retain a hold on his wife in return whereof it is obligatory on him to provide maintenance to her." 32 Both parties have conjugal rights ${ }^{33}$ and should not be cruel towards each other. ${ }^{34}$

\section{Proving the existence of a marriage}

The Marriage Act provides for ways in which the existence of a marriage may be proved. ${ }^{35}$ Courts have held that there are different ways a Muslim marriage can be proved. In In re Estate of Ramadhan Hassan (Deceased) ${ }^{36}$ the Kadhi's Court held that:

27 Id at 5.

28 Id at 5-6.

29 Id at 6.

30 HAA $v$ JOG [2018] eKLR at 4.

31 NUFR $v$ MSC [2015] eKLR, para 27.

32 DNG $v$ AOP [2016] eKLR, para 8.

33 RDJ $v$ AHW [2016] eKLR (Kadhi Court); AAD v AM [2015] eKLR.

34 AA $v$ AS [2004] eKLR at 4; SMH $v$ AHA [2018] eKLR.

35 Sec 59 of the Act.

36 In re Estate of Ramadhan Hassan (Deceased) [2014] eKLR. 
"The question whether there was a marriage or not is one of fact ... [M]arriage may be proved directly or presumptively; directly by means of the oral testimony of the witnesses present at the marriage or by documentary evidence in the shape of a certificate of marriage signed by both parties and their witnesses; presumptively by statement of parties or by evidence of conduct and reputation." 37

The High Court held that "[w]hat constitutes an Islamic marriage is ... a matter of fact to be proved strictly." ${ }^{38}$ In NNS $v$ SAM, ${ }^{39}$ the High Court held that a "marriage certificate is enough proof of" the fact that the parties celebrated their marriage according to Islamic law. ${ }^{40}$ Although a marriage certificate "is recommended", its non-existence does not invalidate a Muslim marriage. ${ }^{41}$ The Kadhi's Court held that the purpose of a marriage certificate is "to remove disputes". ${ }^{42}$ Apart from a marriage certificate, there are other ways in which one can prove that a Muslim marriage took place. These other ways have included producing the notes of the Kadhi who solemnized the marriage and calling witnesses to testify that the marriage was celebrated and the dowry was paid. ${ }^{43}$ Some Muslim scholars argue that the mere fact that there were no witnesses to the marriage does not make it void. ${ }^{44}$ Where there are witnesses, they must convince the court that the marriage in question met the requirements of a valid Muslim marriage. ${ }^{45}$

\section{Conditions of a valid marriage}

Muslim marriages are also governed by the Marriage Act, which provides for some of the conditions that have to be met for such marriages to comply with the Act. However, as the discussion below illustrates, in Islamic law some of these conditions are not a prerequisite for the validity of a marriage between people who profess the Islamic faith (both parties are Muslim) or a marriage between a Muslim man and a non-Muslim woman. Section 48 of the Marriage Act regulates marriages between "persons who profess the Islamic faith". ${ }^{46}$ Both the High Court and the Kadhi's Court held that section

\footnotetext{
37 Id at 4.

38 NUFR $v$ MSC, above at note 31, para 27. See also, In re Estate of Lante Osman Sharriff Omar Noor A.K.A. (Osman Omar) (Deceased) [2015] eKLR, para 17.

39 NNS $v$ SAM [2002] eKLR.

40 Id at 1. See also, MSR $v$ NAB [2017] eKLR (High Court).

41 In re estate of Mohamed Kismala [2017] eKLR, para 10 (Kadhi's Court).

42 Id, para 12.

43 Stephen Boru Elisha $v$ Habiba Mohamed Said $\mathcal{E} 2$ others, above at note 11 at 2 . In re estate of Mohamed Kismala, above at note 41, para 10 (Kadhi's Court).

44 In re Estate of Ramadhan Hassan (Deceased), above at note 36 at 4.

45 NUFR $v$ MSC, above at note 31, para 30; In re Estate of Lante Osman Sharriff Omar Noor A.K.A. (Osman Omar) (Deceased), above at note 38, para 17.

46 The marriage could be between a Kenyan and a foreign national, see Khatija Ramtula Nur Mohamed $\mathcal{E}$ another $v$ Minister for Citizenship and Immigration $\mathcal{G} 2$ others [2015] eKLR (the husband was a Pakistani).
} 
48 "provides for Islamic Marriages". ${ }^{47}$ Section 49 provides that such a marriage has to be "officiated by a kadhi, sheikh or imam as may be authorised by the Registrar and celebrated in accordance with Islamic law". Under section 6(3) of the Marriage Act, customary marriages and marriages celebrated according to Islamic law are polygamous or presumed to be polygamous. Section 8 of the Act provides for circumstances in which a marriage may be converted from a polygamous one to a monogamous one. It is to the effect that:

“(1) A marriage may be converted from being a potentially polygamous marriage to a monogamous marriage if each spouse voluntarily declares the intent to make such a conversion. (2) A polygamous marriage may not be converted to a monogamous marriage unless at the time of the conversion the husband has only one wife."

The Act is silent on how a customary marriage can be converted into a Muslim marriage. Both these types of marriage are polygamous, or potentially polygamous, but they are governed by different rules and parties are entitled to different rights. ${ }^{48}$ This is an issue that the High Court and the Court of Appeal have dealt with, as the discussion below illustrates. When a person converts from Christianity to Islam and conducts a marriage according to Islamic law, such a marriage is governed by Islamic law. However, if parties conducted their marriage according to customary law before converting to Islam, their conversion to Islam does not automatically change their marriage from a customary one to a Muslim one; they are supposed to convert it into an Islamic marriage. As the High Court held in RMM v M a.k.a. JKM. ${ }^{49}$

"The parties herein converted to the Islamic faith in 1994 eight years after entering into a marriage under Kamba customary law. There was no evidence adduced of conversion of the marriage into an Islamic law marriage as there was no ceremony performed as required by Section 49(1) of the Marriage Act, 2014." ${ }^{50}$

The Court added that:

"In order for a marriage conducted under whichever [regime] to be valid, it should meet the legal requirements provided by the Marriage Act... Change of religion does not of itself convert a marriage to the new religion. The parties

47 LHJ v AGD [2020] eKLR, para 18 (Kadhi's Court); MSR v NAB, above at note 40 at 2 (High Court).

48 For example, although sec 10(1)(a) of the Act prohibits any person from marrying, amongst other people, his or her cousin, sec 10(4) makes it clear that that prohibition is not applicable "to persons who profess the Islamic faith".

49 RMM $v$ M a.k.a. JKM, above at note 25.

50 Id, para 37. 
must take steps to ensure the law is complied with. Converting a marriage from one type to another is a legal process. It cannot be equated to change of religion where a word of mouth is sufficient evidence of conversion." ${ }^{51}$

If the marriage is not "re-celebrated under the couple's newfound faith", it "remained a customary one subject to the laws governing marriages contracted under customary law". ${ }^{52}$ In coming to this conclusion, the High Court referred to section 49(1) of the Act. This implies that people who convert to Islam after having celebrated a customary marriage also have to ensure that they perform a ceremony to change their marriage from a customary one to a Muslim one. Therefore, their marriage would now have to be presided over by one of the people mentioned under section 49(1) of the Act. However, the Court of Appeal and the High Court's conclusions on this issue are not supported by Islamic law. According to Islamic law, when a couple converts to Islam, they keep their marriage contract and their marriage automatically becomes a Muslim marriage. ${ }^{53}$ Therefore, in the event of a divorce, such a marriage is governed by Islamic law.

Neither the Marriage Act nor the Kadhis' Courts Act stipulates the conditions for a valid Muslim marriage. However, a close examination of case law reveals these conditions. In RWK $v$ AMA ${ }^{54}$ the Kadhi's Court, based on a textbook on Islamic law, gave some of the conditions of a valid marriage: the parties must be of sound mind, they must have attained the age of marriage, and they must consent to the marriage. ${ }^{55}$ The marriage must be between a man and a woman ${ }^{56}$ and there is no requirement of a ceremony or special formality for the marriage to be valid. ${ }^{57}$ In Council of Imams and Preachers of Kenya, Malindi $\& 4$ others $v$ Attorney General $\& 5$ others ${ }^{58}$ in which an underage girl contracted an Islamic marriage, the High Court held that that marriage was void because, under Kenyan law, only persons aged 18 years and above can get married. Section 49(1) of the Marriage Act provides for people who are allowed to officiate at Islamic marriages. Another requirement is that the groom has to pay a dowry to the bride. The dowry aspect of the marriage has to be dealt with in accordance with Islamic law and not in accordance with customary

51 Id, para 44.

52 Id, para 43. See also RMM $v$ BAM [2015] eKLR, para 5.

53 See MS Al-Munajjid, "Husband and wife converted together; do they need to do a new marriage contract?” 21 April 1999, available at https://islamqa.info/en/answers /4035/husband-and-wife-converted-together-do-they-need-to-do-a-new-marriage-contract (last accessed 9 January 2020).

54 RWK $v$ AMA [2015] eKLR.

55 Id at 4. See also SMK $v$ RHH, above at note 26 at 6; MEM $v$ AD [2015] eKLR at 3 (Kadhi's Court).

56 In re Estate of IOI (Deceased) [2019] eKLR, para 10.

57 In re Estate of Ramadhan Hassan (Deceased), above at note 36 at 3.

58 Council of Imams and Preachers of Kenya, Malindi $\& 4$ others $v$ Attorney General $\& 5$ others [2015] eKLR. 
law. 59 The mention of the amount of the dowry at the time of the nikkah [marriage] is not a prerequisite for the validity of a marriage. ${ }^{60}$ There is a difference between dowry and bride price. The High Court held in FBI $v$ BG that ${ }^{61}$

“"[B]ride price' and 'dowry' are two different things, though the two have often been confused to mean the same thing. Bride price is a gift or payment made to the parents of the bride at marriage, while dowry is a gift given to the woman in a marriage, which becomes her sole property. The promise of dowry in the marriage is a contract and in my view is enforceable." 62

Another requirement is that the "consent of guardian [waliyy] is a condition to the validity of any marriage. In cases of women Muslim reverts, normally the waliyy is the Kadhi."63

If a Muslim man denounces his religion, the marriage between him and the Muslim woman ceases to exist. ${ }^{64}$ Although a Muslim man is permitted to marry a non-Muslim woman, the Kadhi's Court held that "[t]he change to Christianity and the requirement of belief that Jesus is Lord (not prophet) as herein ... renders ones [sic] belief a nullity in Islam and was enough to dissolve the marriage herein." ${ }^{5}$ Although in practice the fact that a person has converted from another religion to Islam may be proved by oral evidence, in some cases a certificate of "reversion to Islam" or confession to Islam is issued. ${ }^{66}$ There is conflicting jurisprudence from the Kadhi's Court and the High Court on whether the concept of presumption of marriage exists in Islamic law. ${ }^{67}$ Some jurisprudence supports the concept of presumption of marriage ${ }^{68}$ whereas others do not. ${ }^{69}$ The Court of Appeal has not found it necessary to express an opinion on whether Islamic law recognizes the concept of presumption of marriage. ${ }^{70}$ In SMK $v$ RHH, ${ }^{71}$ the Kadhi's Court held that although some schools of thought are of the position that a marriage which is contracted at the time when the

59 RMM $v$ M a.k.a. JKM, above at note 25, para 47.

60 NAH $v$ SBK [2016] eKLR at 3; SK $v$ HM [2018] eKLR at 2 (Kadhi's Court).

61 FBI $v$ BG, above at note 15.

62 Id, para 40.

63 RWK $v$ AMA [2016] eKLR, para 33.

64 In Sakina Sote Kaittany \& another v Mary Wamaitha [1995] eKLR at 22, the Court of Appeal held that "[s]ince there is a complete prohibition of a muslim woman marrying a nonmuslim and then if a muslim man married to a muslim woman renounces the Islamic faith the marriage is dissolved at the time of renouncing the Islamic faith."

65 OSM $v$ MMO [2019] eKLR, para 18.

66 JAOO $v$ HSA [2015] eKLR, para 7; RB $\mathcal{E}$ RGO $v$ HSB \& A.S.B [2014] eKLR, para 18.

67 The principle of presumption of marriage is well established in Kenyan law, see, for example, In re Estate of George Robinson Wangome Thiga (Deceased) [2019] eKLR, paras 19-21.

68 In re Estate of Ramadhan Hassan (Deceased), above at note 36 (Kadhi's Court); HW $v$ GDB [2016] eKLR, paras 14-15.

69 In re Estate of CCBH (Deceased) [2017] eKLR.

70 CKC $\mathcal{E}$ another (Suing through their mother and next friend JWN) $v$ ANC, above at note 2.

71 SMK $v$ RHH, above at note 26. 
woman is pregnant from fornication is invalid, in its opinion, based on the Shafii and Hanafi schools of thought, such a marriage is valid under Islamic law. ${ }^{72}$ The Court also added that if the husband gets to know that the wife was pregnant out of wedlock shortly after contracting the marriage, but nevertheless remained in that marriage for a long period, in this case ten years, under the law of contract he is prohibited by the principle of estoppel from challenging the validity of the marriage. ${ }^{73}$ This now brings us to the issue of inheritance should one of the parties to the marriage die.

\section{PRINCIPLES OF INHERITANCE IN ISLAMIC LAW AS EXPLICATED BY KENYAN COURTS}

According to the Kadhi's Court, leading Islamic law scholars have shown that the Islamic law of inheritance is detailed. ${ }^{74}$ This could explain why Muslims in Kenya, before and after independence, have always lobbied different governments to have their estate distributed according to Islamic law. ${ }^{75}$ It is against that background that the Kenyan Law of Succession Act does not, as a general rule, apply to Muslims. ${ }^{76}$ However, section 2(4) of the Succession Act provides that "the provisions of Part VII [of the Act] relating to the administration of estates shall where they are not inconsistent with those of Muslim law apply in case of every Muslim". The High Court held that "[t]he only provisions of the Act that are applicable to the estate of the Muslim as per Section 2(4) are the procedural provisions contained in Part VII of the Act relating to administration of estates."77 In other words, "substantive provisions of the Act are not applicable to testamentary or intestate succession to the estate of any person who at the time of his death is a Muslim". ${ }^{78}$ Since the Kadhis' Courts Act does not define the term "estate", the High Court has relied on the Succession Act for the definition of the term. ${ }^{79}$ The High Court held that:

"Under Islamic law of inheritance, whatever belonged to the deceased or whatever the deceased was entitled to form part of his estate and is available for distribution to the heirs.... Islamic Law of inheritance makes no difference on the type of property heritable by the heirs provided that it has monetary value and it is halal (lawful)." ${ }^{80}$

Id at 5 .

Id at 6-7.

In re Estate of Ramadhan Hassan (Deceased), above at note 36, para 9.

75 Zulekha Salim Bantushi \& another $v$ Shehuna Mohammed Modhihiri; Ahmed Modhihiri Mohamed (Interested Party) [2019] eKLR, para 20.

76 Id, paras 20-22.

77 Fatuma Rama Mwaurinda \& another v Kusi Mukami Mwaurinda [2017] eKLR, para 10. See also Mariam Mathias Mwasi v Rama Adam [2020] eKLR, para 21.

78 Mustaq Alimohamed $v$ Mohamed Iqbal Mohamed \& 2 others [2020] eKLR, para 21.

79 Ahmed Abbas Edin $\mathcal{G}$ Abdinasir Adan Somo $v$ Hassan Abdul Adan [2018] eKLR at 9.

80 Mako Yassin $v$ Hribaye Nane Shege $\& 2$ others, above at note 15 at 3. 
The property is not limited to real property and tangible property, but also includes pension and death gratuity. ${ }^{81}$ Hence, "[a]ll types of properties are subject to inheritance under Islamic law." 82 However, the deceased's estate does not include the money being paid to the widow in her capacity as a widow or the property that was sold by the deceased in his lifetime ${ }^{83}$ and the property he holds in trust on behalf of others. ${ }^{84}$ The Kadhi's Court held that the estate of a deceased Muslim should be spent in the following sequence: payment for burial expenses on condition that the burial should not be extravagant; paying his debts where there is proof of the same; and distribution amongst the heirs according to Islamic law. ${ }^{85}$

According to the Kadhi's Court, the right of inheritance is based on four conditions: "death of the propositus, existence of legal heirs, existence of estate and establishment of nexus between the deceased and the beneficiaries". ${ }^{86}$ In Mohamed Juma $v$ Fatuma Rehan Juma $\& 6$ others, ${ }^{87}$ the Kadhi's Court held that in Islam the principle of devolution is followed and that for a person to inherit from a deceased Muslim, he/she has to fall into one of the three categories of heirs. According to the Court:

"Heirs according to the Mohammedan Law are classified in three (3) categories herein namely: Ahlul - Faraidh (Quranic Sharers), Asabah (Residuary or agnates), Dhawil - Arham (Distant kindred/Uterine relatives)....The first rule of intestate succession is that the Quranic sharers must first ... be assigned their shares. The Quranic sharers are the most important class of heirs who take primacy.... The second rule of intestate Succession is that whatever [is] left after assigning the first class their share (residue) should go to the heirs of the second class, names [sic] the Asabah or Agnates, also known as the Residuaries, because they take the residue of the estate of the deceased person....The distant kindred or Dhawil - Arham (uterine relatives)... Assigning these classes of heirs the respective shares if any is done in the following manner: Firstly, the Quranic sharers are assigned to their entitlement in accordance to the primary sources of Sharia. Secondly, if there be any residue after assigning the Quranic sharers the respective shares the Residuaries become entitled to certain shares as provided by the primary sources of Sharia. Thirdly, the distant kindred can only inherit intestate in [the] absence of the first and the second class." ${ }^{88}$

81 Ibid.

82 Mohamed Hanif Kherdin $v$ Mohamed Sheriff Khairdin [2016] eKLR, para 2.

83 Mako Yassin v Hribaye Nane Shege $\& 2$ others, above at note 15 at 4.

84 In re Estate of Lante Osman Sharriff Omar Noor A.K.A (Osman Omar) (Deceased), above at note 38, para 14.

85 In re Estate of Juma Badadi Abaroba (Deceased) [2019] eKLR at 2.

86 In re Estate of IOI (Deceased), above at note 56, para 7.

87 Mohamed Juma $v$ Fatuma Rehan Juma \& 6 others [2017] eKLR.

88 Id, at 3-4 (the Court outlines all these categories of heirs). See also In re Estate of Mwangi Suleiman Kahiu (Deceased), above at note 20 at 2. 
Islamic law allows a beneficiary to reject his/her share of the deceased's estate. ${ }^{89}$ The Kadhi's Court has the jurisdiction to deal with cases of inheritance whether or not the deceased left a will and "irrespective of the value of the estate". ${ }^{90}$ Under Islamic law, a will can be verbal or written. ${ }^{91}$ The High Court held that "[t]he functions of a succession or inheritance court is to ascertain the assets of the estate, the beneficiaries or interested parties in the estate, and distribute the assets less any liabilities according to the law, in this particular case Islamic Law." 92 In Ahmed Abbas Edin $\mathcal{G}$ Abdinasir Adan Somo $v$ Hassan Abdul Adan, ${ }^{93}$ the High Court held that all children have a right to inherit from their mother according to Islamic law. ${ }^{94}$ Against that background, the Court distributed the deceased's estate as follows: "There are four sons and three daughters. The share of a son is twice that of a daughter. This gives a total of eleven (11) shares. Each son gets $2 / 11$ share while each daughter gets $1 / 11$ share of the deceased's estate." 95

The Court also appointed two of the appellants and one of the respondents to be administrators of the estate in order to give effect to its judgment. ${ }^{96}$ Although the Court does not state it expressly, the formula it adopted to distribute the property is based on the Quran chapter 4, verses 11 and 12. These are the verses that the High Court in other decisions and the Kadhi's Court have relied on to distribute the estate of deceased Muslims. If a deceased Muslim leaves a will, it has to comply with Islamic law, otherwise a court will declare it invalid and distribute the estate according to the teachings of Islam. ${ }^{97}$ This raises the question of the right to freedom of testation.

Where a Muslim dies intestate, the Kadhi's Court will distribute his estate to his/her heirs. ${ }^{98}$ The High Court held that, according to the Quran, "a divorced woman has no right to inherit property from her former husband". 99 The role of an administrator is to ensure that he/she distributes the estate to the heirs as soon as possible. ${ }^{100}$ The Kadhi's Court held that the reason why all the estate of the deceased has to be distributed upon his/her death is because "Islamic

89 In re Estate of Mwangi Suleiman Kahiu (Deceased), above at note 20 at 3.

90 Fatuma Anab Mohamed Haji \& 5 others $v$ Asha Abdullahi $\mathcal{E} 3$ others [2018] eKLR, para 25.

91 Ramadhan Mustafa $v$ Zulfa Ngasia Juma, above at note 12, para 21; In re Estate of OSS (Deceased) [2015] eKLR, at 5 (Kadhi's Court).

92 Fatuma Anab Mohamed Haji $\& 5$ others $v$ Asha Abdullahi $\& 3$ others, above at note 90, para 38.

93 Ahmed Abbas Edin $\mathcal{G}$ Abdinasir Adan Somo v Hassan Abdul Adan above at note 79.

94 Id at 11.

95 Ibid.

96 Ibid.

97 In re Estate of Mohamed Kinango Kitonyo (Deceased) [2019] eKLR, para 1; ASM v LMM [2016] eKLR, p. 2 (Kadhi's Court); Fadhiya Salim Faraj v Faiz Mohamoud Abdalla, above at note 17 (High Court).

98 Amongst the many cases, see In re Estate of Omari Hiribae Omari (Deceased) [2016] eKLR; In re Estate of Juma Badadi Abaroba (Deceased), above at note 85; ASM v LMM, above at note 97 at 2 .

99 Ramadhan Mustafa $v$ Zulfa Ngasia Juma, above at note 12, para 40.

100 In re estate of Mohamed Kismala, above at note 41, para 31. 
law of succession did not recognize the concept of administration of estate of the deceased muslims. It merely laid down machinery for the distribution of the estate of the deceased among the legatees and the heirs." 101 Whoever is in charge of distributing the deceased's estate must ensure that he follows the formula laid down in the Quran "no matter the complexity" of the estate. ${ }^{102}$ For a person to administer the estate of a deceased Muslim, he/she does not require letters of administration because such letters are not a requirement in Islamic law. ${ }^{103}$ A proper valuation of the deceased's estate has to be conducted before the estate is distributed for the administrator to determine the exact percentage each beneficiary is entitled to. ${ }^{104}$ In some cases the High Court had ordered the Kadhi's Court to distribute the deceased's estate but without stating the formula to be used. ${ }^{105}$ In these cases, the Kadhi's courts follow the formula in Quran as their mandate is to apply Islamic law. ${ }^{106}$

\section{Gifts and bequeathing the whole estate to one person}

Although a Muslim can make a bequest in his will, this is subject to limitations. In Mohamed Athman Kombo $v$ Maua Mohamed ${ }^{107}$ the High Court referred to various verses of the Quran and Hadiths and held that "[u]nder Islamic Sharia a Muslim may not make a bequest in his will in favour of a legal heir. This is because Allah legislated fixed shares for legal heirs." 108 Where the deceased died intestate but made an affidavit in which he donated some of his property to a person, for example his child, the donation is valid but the remaining "properties have to be distributed to the beneficiaries in accordance with Islamic Law of Inheritance" ${ }^{109}$ However, there is a limitation on the amount that the deceased is allowed to will-out, which is one-third of the estate. The rationale behind this is "that the deceased must have some inheritance to the lawful heirs". ${ }^{110}$ In Fatuma Anab Mohamed Haji \& 5 others $v$ Asha Abdullahi $\& 3$ others $^{111}$ the High Court held, based on the submissions made by counsel for the parties, that:

101 Maimuna Kenyi Suleiman v Amina Ibrahim [2016] eKLR at 6. See also In re Estate of Omari Hiribae Omari (Deceased), above at note 98 at 2 (Khadi's Court); In re estate of Kassim Islam (Deceased) [2015] eKLR at 2 (Khadi's Court).

102 In re Estate of Ramadhan Hassan (Deceased), above at note 36 at 9.

103 In re estate of Mohamed Kismala, above at note 41, paras 33-35 (Kadhi's Court).

104 In re Estate of Mohamed Kinango Kitonyo (Deceased), above at note 97, para 2; In re Estate of Rehema Binti Said Msonek (Deceased) [2015] eKLR.

105 Mako Yassin $v$ Hribaye Nane Shege $\mathcal{\sigma} 2$ others, above at note 15 at 4-5.

106 See, for example, Mohamed Athman Kombo v Maua Mohamed, above at note 17, para 3; Fadhiya Salim Faraj $v$ Faiz Mohamoud Abdalla, above at note 17, para 31; MAH E another $v$ HIO [2014] eKLR, para 3.

107 Mohamed Athman Kombo v Maua Mohamed, above at note 17.

108 Id, para 13.

109 Fatuma Anab Mohamed Haji \& 5 others $v$ Asha Abdullahi $\& 3$ others, above at note 90, para 48.

110 Ramadhan Mustafa $v$ Zulfa Ngasia Juma, above at note 12, para 21. See also In re Estate of OSS (Deceased), above at note 91 at 3.

111 Fatuma Anab Mohamed Haji \& 5 others $v$ Asha Abdullahi \& 3 others, above at note 90. 
"[T]here are three conditions under Islamic Law for making a gift before death on property. The first condition is that the gift should be made by the owner of the property. The second condition is that the gift should be accepted by the donee of the property. The third condition is that the donee of that property should take possession of it."112

The Court, without referring to any authority, held that "[t]here appears to be no requirement under Islamic Law that the gift be witnesses [sic] or signed by a witness." 113 A gift by the deceased which was made contrary to Islamic law is a nullity. ${ }^{114}$ The property that the deceased gifted away is not available for distribution as part of his estate. ${ }^{115}$ The same rule applies to the deceased's property that was stolen or fraudulently sold. ${ }^{116}$ The Kadhi's Court held that Islamic law permits a Muslim to give away all his/her property to his/her heirs as gifts before his/her death, provided that the males get twice the share of females. ${ }^{117}$

Another issue is whether a Muslim man who does not have any children can bequeath all his estate to his wife. In In the Matter of the Estate of Ishmael Juma Chelanga - Deceased ${ }^{118}$ the High Court held that:

\begin{abstract}
"It is a fallacy on the part of many widows ... to hold the view ... that after the death of their husbands, they shall take possession of all immovable property left by them, under the false impression that they are the owners of everything. The fact is that: anything their late husbands gifted them during their lifetime and handed over to them as being theirs, is no doubt theirs. But the rest of it is combined inheritance and, according to the rules of Shariah, this will be distributed among all heirs as a matter of obligation. A widow does not therefore own the whole of a deceased husband's property. She owns only that share which she is entitled under the law."119
\end{abstract}

About a decade later, the High Court was confronted with a case in which the above ruling was tested and an exception had to be created. In Saifudean Mohamedali Noorbhai $v$ Shehnaz Abdehusein Adamji120 the deceased, who did not have a child, bequeathed all his estate to his wife. His cousin argued that this was contrary to the Islamic law principle of representation, which is to the effect that "in the absence of brothers, uncles or aunts, their

\footnotetext{
112 Id, para 44.

113 Id, para 45.

114 In re Estate of OSS (Deceased), above at note 91 at 4 (Kadhi's Court).

115 Mohamed Hanif Kherdin v Mohamed Sheriff Khairdin, above at note 82 (Kadhi's Court).

116 Ibid.

117 In re Estate of Habiba Galgalo Guyo [Deceased] [2018] eKLR.

118 In the Matter of the Estate of Ishmael Juma Chelanga - Deceased [2002] eKLR.

119 Id at 13.

120 Saifudean Mohamedali Noorbhai v Shehnaz Abdehusein Adamji [2011] eKLR.
} 
respective children take their share". ${ }^{121}$ He argued that he was entitled to two-thirds of the deceased's estate. However, the wife argued that the deceased deliberately excluded his cousins from his will and that that is permissible in Islamic law. ${ }^{122}$ The Court referred to examples from Pakistan to support its view that there are circumstances in which Islamic law can be interpreted to address an injustice if its strict interpretation would lead to the opposite results. ${ }^{123}$ Against that background and in dismissing the appeal, it observed that:

\begin{abstract}
"Muslim courts, jurists and law makers have, when necessary, sought to ensure that the humane intention of the law be upheld, whether to protect the interests of widows or orphaned grandchildren whom, a rigid reading of the letter of the law, would have deprived of much needed and expected support. In construing the will of the deceased, therefore, the pertinent question to ask is whether he would have happily contemplated to see his widow and life-time companion, whose care and protection was a solemn duty imposed upon him by the Quranic teachings, deprived of three quarters of his estate in favour of a cousin, a person presumably of independent means, and a person who has not been shown to have had, or likely to have, any concern or interest in the welfare of the respondent. Nor can any court of law, acting in good conscience and charged with the duty of administering justice and equity, a duty which also resonates with the Quaranic injunction emphasising justice and kindness - entertain such a contemplation." ${ }^{124}$
\end{abstract}

The importance of this case lies in the fact that the Court is ready to disregard Islamic law that is contrary to what it considers to be principles of justice. In effect, the judgment shows that there are circumstances in which a Muslim man of a Shia sect can bequeath all his estate to his wife. This principle is likely to be contested by Sunni Muslims. This is so because the Chief Kadhi of Kenya had already invoked the principle of devolution or representation to hold that the appellant, the deceased's cousin, was entitled to two-thirds of the estate. If, for example, the husband helps the wife to build her house, such a house belongs to her and it does not form part of his estate that is distributed after his death. ${ }^{125}$

\title{
HUMAN RIGHTS ISSUES ARISING FROM ISLAMIC LAW ON INHERITANCE AND CHILDREN
}

In this part of the article, the author deals with three issues that raise human rights questions in the context of inheritance. These issues are: children born

121 Id at 9.

122 Ibid.

123 Ibid.

124 Id at 10.

125 Aweoha Mohamed Said \& another v Khadija Abeid Juma [2005] eKLR. 
out of wedlock and non-Muslims and whether they can inherit from a Muslim; the formula used to distribute the estate; and Muslims and freedom of testation.

\section{Children born out of wedlock and non-Muslims}

Whether a non-Muslim or a child born out of wedlock can inherit from a Muslim is an issue that Kenyan courts have dealt with, and the jurisprudence on this issue is still evolving. The Kadhi's Court has the jurisdiction to determine whether a Christian can inherit from a Muslim. ${ }^{126}$ In In re Estate of CCBH (Deceased) ${ }^{127}$ the High Court dealt with the question of whether Islamic law that provides that "illegitimate children" and their mother, who was not married to the deceased Muslim, cannot inherit from their deceased father is unconstitutional for being discriminatory against them on the ground of religion and also for violating their right to property. In this case, there was evidence that the young children were dependent on their father before his death. The applicants referred to various regional and international human rights instruments which guarantee the right to equality. ${ }^{128}$ The Court held that the Constitution does not provide for an absolute right to equality and that Kenyan law allows Muslims to administer their estate in accordance with Islamic law. ${ }^{129}$ The Court emphasized that Islamic law was very clear that "illegitimate" children and non-Muslims do not inherit from a deceased Muslim. ${ }^{130}$ In dismissing the application, the Court reasoned that it was sympathetic to the children, but added that it:

"[M] ust fault the deceased and S [the children's mother]. This is because, they being Muslims, were well aware that the Applicants are not recognised as heirs of either the deceased or $S$ under Islamic Sharia. To forestall the sorry situation the Applicants are now in, the deceased and S ought to have made provision for them by way of will. Islam recognises the testamentary freedom of Muslims. A Muslim may dispose of his estate by will to non-heirs but up to $1 / 3$ thereof." 131

In Ramadhan Mustafa $v$ Zulfa Ngasia Juma ${ }^{132}$ one of issues that the High Court dealt with was whether the deceased's daughters who had married Christian men could inherit from their father's estate. The record of the Kadhi's Court showed that these daughters had not been recognized by the Kadhi as some of the children who were entitled to inherit from their father because

126 Stephen Boru Elisha v Habiba Mohamed Said $\mathcal{E} 2$ others, above at note 11 at 3.

127 In re Estate of $\mathrm{CCBH}$ (Deceased), above at note 69.

128 Id, paras 16-19.

129 Id, paras 20-21.

130 Id, paras 21-24.

131 Id, para 25.

132 Ramadhan Mustafa v Zulfa Ngasia Juma, above at note 12. 
the Kadhi "agreed with the proposition that the daughters who were marred [sic] to Christians should not inherit from their father". ${ }^{133}$ The Court also observed that these daughters had not only married Christian men, they had also "changed their names to Christian/English names". ${ }^{134}$ The High Court had to decide whether the Islamic teaching that such daughters, who had married Christian men and changed their names, could not inherit from their father was contrary to article 27 of the Constitution, which prohibits discrimination on, amongst others, the ground of religion. ${ }^{135}$ The Court held that:

"[T]he provision of equality under Art 27 of the Constitution of Kenya in so far as it relates to the question of shariah is qualified by the provisions of Art 24 (4) of the Constitution which proves that: (4) The provisions of this Chapter on equality shall be qualified to the extent strictly necessary for the application of Muslim law before the Kadhi's courts, to persons who profess the Muslim religion, in the matters relating to personal status, marriage, divorce and inheritance." ${ }^{136}$

The Court concluded that the Kadhi's Court made a correct decision when it held that the daughters could not inherit from their father. ${ }^{137}$ This High Court decision makes it very clear that a non-Muslim does not inherit from a Muslim, and it is in line with early case law in which the High Court held that non-Muslims (children and other relatives) cannot inherit from a Muslim and that "an illegitimate" child does not inherit from his/her father. $\mathrm{He} /$ she can only inherit from their mother. ${ }^{138}$

However, six months later, in the case of CKC $\mathcal{E}$ another (Suing through their mother and next friend JWN) $v$ ANC,139 the Court of Appeal reached a different conclusion - but the facts were different. The issue for the Court to determine was "whether the appellants, children born of a Muslim father and a non-Muslim mother who were not formally married, can inherit the estate of their deceased father." ${ }^{140}$ Both the Kadhi's Court and the High Court had held that Islamic law applied to the estate of the deceased and that this meant that the children, who were non-Muslim and born outside marriage, could not inherit from his estate. ${ }^{141}$ The children argued that being non-Muslims, they could inherit from their father because Islamic law did not apply to them, and therefore the Kadhi's Court did not have jurisdiction

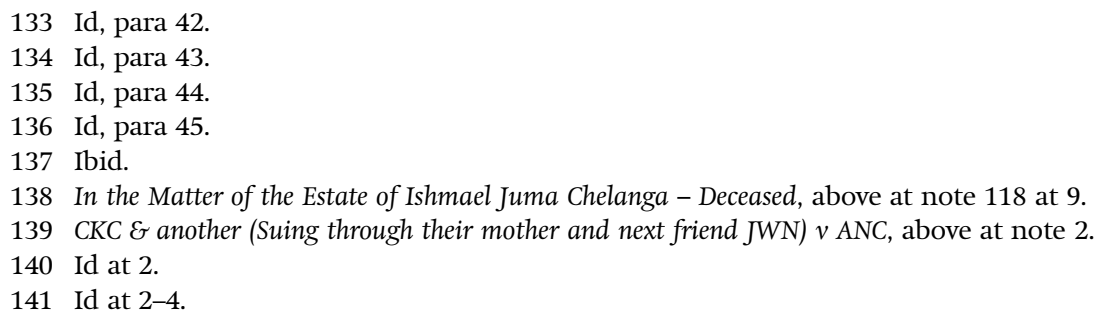


over the matter because they did not profess the Islamic faith and had not submitted to its jurisdiction. They also argued, inter alia, that Islamic law was discriminatory against them on the ground of religion and therefore unconstitutional. ${ }^{142}$ The respondents argued, inter alia, that Islamic law applied to the estate and that article 24(4) of the Constitution was applicable. ${ }^{143}$ Before resolving the issues raised by the parties, the Court referred to its earlier jurisprudence, laying down a few basic principles relevant to Islamic law in the following terms:

"The first is that Islamic law is a moral doctrine at whose heart lie the values of justice and kindness translating into an ethic of care and compassion for the weak and vulnerable, especially among one's close relations. Secondly, in interpreting the Quran-inspired law, regard must be had to the Quran's moral teaching as a whole. Thirdly, Islamic law is dynamic and adapts to evolving social, political, cultural and economic conditions and realities and that "not all rules of inheritance are rigidly fixed for all times since the development of Muslim jurisprudence has been and continues to be a search for the good law to be applied in differing times and situations." Lastly,... Islamic law does not constitute a single uniform code of law. On the contrary, its hallmark is legal pluralism and diversity, comprising a multiplicity of Muslim schools of law within the two major branches of Sunni and Shia."144

The Court also observed that:

"The singular handicap that we face in this appeal is that the record does not show the Islamic school of thought that [the deceased] belonged to. The principal Kadhi held that according to the Islamic law that was applicable to him, children born out of wedlock were not entitled to inherit from their father, which of course seems to be diametrically at variance with the principles of justice and kindness adverted to above."145

Against that background, the Court discussed the constitutional provisions on the right to equality, the national values, the right of access to court, the rights of vulnerable groups such as women and children and constitutional interpretation. ${ }^{146}$ The Court held:

"That the appellants were born out of wedlock following a prolonged and open relationship between $S$ [their father] and $\mathrm{J}$ [their mother] is not a fault of theirs. The fault, if it be a fault at all, falls squarely on the shoulders of S and J. It is

142 Id at $4-5$.

143 Id at 5.

144 Ibid. Emphasis removed.

145 Ibid.

146 Id at 5-7. 
common ground that the appellants do not profess the Islamic faith and have not submitted themselves to the jurisdiction of the Kadhi's court. Professing the Islamic faith and voluntarily submitting to the jurisdiction of the Kadhi's court are absolute preconditions for application of Islamic law to the appellants.... Those preconditions have not been satisfied ... and therefore the principles of Islamic law cannot be applied to the appellants." ${ }^{147}$

The Court added that the conclusion it reached "most favours" the rights in the Bill of Rights. ${ }^{148}$ However, the Court did not find it necessary to decide whether the Islamic law of inheritance was unconstitutional. It added that in cases where the "strict conditions" it had laid down are complied with, "the Constitution allows application of Islamic law even though it may be perceived as discriminatory". ${ }^{149}$

Whether or not the Court of Appeal's understanding of the application of Islamic law to the distribution of the estate of a deceased Muslim is correct is debatable. The starting point is to refer to section 2 of the Succession Act, ${ }^{150}$ which states that as a general rule the Succession Act does not apply to the estate of a deceased Muslim. The effect of section 2(3) of the Succession Act is to ensure that the estate of a deceased Muslim is governed by Islamic law. Islamic law provides the exact shares to which each beneficiary is entitled. A Muslim does not have a choice between having his estate dealt with in terms of the Islamic law or the Law of Succession Act. This is because section 2(3) makes it very clear and in mandatory terms that the estate of a Muslim "shall be governed by Muslim law". This is important because the word "shall" is used and means that it imposes a mandatory condition.

The problem with the Court of Appeal's reasoning is that it conflated two issues: the jurisdiction of the Kadhi's Court and the application of Islamic law to the estate of a deceased Muslim. Whereas the Court is correct in its reasoning that the Kadhi's Court did not have jurisdiction in the matter because some of the parties to the dispute did not profess the Islamic faith, it was wrong to use that holding to conclude that Muslim law was not applicable to the deceased's estate. It is important to remember that the High Court held that if there is a dispute as to whether the estate of the deceased should be governed by the Succession Act or by Islamic law "[t]he determining factor in deciding the place of suing is not the inheritors but the deceased's personal law. It is the deceased's estate which is the subject of inheritance. Since the deceased died a Muslim, his estates has [sic] to be dealt with through the Kadhi's Court."151 In other words, it has to be governed by Islamic law. There are Court of Appeal and High Court decisions to the effect that whether

147 Id at 8 .

148 Ibid.

149 Id at 9.

150 Cap 160.

151 Stephen Boru Elisha v Habiba Mohamed Said \& 2 others, above at note 11 at 3. 
a succession matter involving the estate of a deceased Muslim is dealt with by the Kadhi's Court or by the High Court, Islamic law is the applicable law. ${ }^{152}$ In cases in which the High Court has exercised jurisdiction over succession matters in which the deceased were Muslims, it has invoked Islamic law, especially the Quran and hadiths, to decide who the beneficiaries are and also the shares of each beneficiary. ${ }^{153}$ Therefore, the court in which the matter is heard is not important at all. What is important is that any court which deals with the estate of a deceased Muslim is obliged by section 2 of the Succession Act to apply Islamic law. The Court has no choice in the matter unless section 2 is declared unconstitutional for violating the freedom of testation. Even then, this may be an uphill task because, as will be discussed below, the freedom of testation is a statutory right provided for under section 5 of the Succession Act and not a constitutional right. The Kadhi's Court has made it very clear, in more than one decision, that the Succession Act is not applicable to the "succession of estates of deceased Muslim",154 and that Part VII of the Law of Succession Act is only applicable to the estate of a deceased Muslim as long as it is not contrary to Islamic law. ${ }^{155}$ In other words, the estate of a deceased Muslim is "exclusively" governed by Islamic law. ${ }^{156}$ Thus, a valid will should state clearly that the estate shall be administered in accordance with Muslim law. ${ }^{157}$

This Court of Appeal's decision, unless reversed by the Supreme Court, is likely to fundamentally change this aspect of Muslim law of inheritance in Kenya in at least two different ways. First, whether or not a non-Muslim will inherit from a Muslim will depend on the Islamic school of thought of the parties, as opposed to that of the presiding Kadhi. This is not an easy task in light of the fact that the Court of Appeal, in its earlier decision, referred to a statement from the International Islamic Conference to the effect that there are eight Islamic schools of jurisprudence. ${ }^{158}$ Although the "Kenyan Islamic

152 See RB $\mathcal{G}$ RGO $v$ HSB $\mathcal{G}$ ASB [2014] eKLR, para 16 (and the decisions discussed therein). See also AS $\mathcal{E} 2$ others $v$ SAM [2014] eKLR, para 17; and In Re Estate of Yakub Umardin Karimbux (Deceased) [2008] eKLR.

153 In re Estate of Mohamed Kinango Kitonyo (Deceased), above at note 97, paras 5-7. See also In re Estate of $\mathrm{CCBH}$ (Deceased), above at note 69, para 1 (the estate must be administered according to Islamic law).

154 In re estate of Mohamed Kismala, above at note 41, para 28.

155 Id, para 33. In re estate of Adamali Gulam Hussein Lakdawalla also known as Gulam Hussein Mulla Allibhai Lakdawala (Deceased) [2015] eKLR at 2.

156 In re Estate of Mwangi Suleiman Kahiu (Deceased), above at note 20 at 1.

157 See, for example, In re Estate of Omar Ali Abdulrahman [2017] eKLR, paras 1 and 17.

158 Saifudean Mohamedali Noorbhai $v$ Shehnaz Abdehusein Adamji, above at note 120 at 3. In some cases where there are differences between the schools of thought on a given issue, the Kadhi's Court will highlight those differences and adopt the ruling of one of the schools depending on the circumstances of the case. See for example, MSA $v$ ILA [2015] eKLR on the question of whether a woman is entitled to maintenance in the case of irrevocable talak. 
practice ... is predominantly Sunni with a Shafi intellectual tradition", 159 the Court of Appeal's ruling is likely to create a situation in which some people will resort to "fatwa-shopping", which means "looking for a favourable fatwa". ${ }^{160}$ As Ricklefs explained, fatwa shopping is possible "[s]ince there is a plurality of understandings of Islam, there is an equally wide range of interpreters, so that fatwas on the same point may dissent from one another."161 Some scholars have argued that the approach of fatwa shopping is good for Muslims as it gives them a variety of sources from which to choose. ${ }^{162}$ However, others have criticized it for, inter alia, opening up a possibility for people who are not qualified in Islamic law to give their rulings on important issues. ${ }^{163}$

Secondly, Kadhi's courts are likely to be barred from dealing with any estate that involves a dispute concerning whether non-Muslims can inherit from Muslims. This is because a correct reading of section 5 of the Kadhis' Courts Act and article 170(5) of the Constitution shows that such courts have no jurisdiction over an issue unless both parties profess the Islamic faith and they submit to the court voluntarily. As a result, all inheritance matters that involve Muslims and non-Muslims will have to be handled by the High Court. However, the High Court would have to follow Muslim law when dealing with the estate of a deceased Muslim. This is so because, as mentioned above, section 2(3) of the Law of Succession Act provides that the estate of a Muslim "shall be governed by Muslim law".164 The High Court held that "[w] hile dealing with the estate of a deceased Muslim, this Court is required by Section 2(3) of the Act to apply Islamic law in the devolution of the estate."165 Depending on the Islamic school of thought adopted by the High Court and the Bill of Rights, in the end, non-Muslims will inherit from Muslims unless there is a compelling reason for the High Court to find otherwise. And surely, the fact of religion cannot be one of the compelling reasons, otherwise the High Court would be acting contrary to the Constitution, which prohibits discrimination on the ground of religion. In effect, the question of whether a non-Muslim can inherit from a Muslim is one to be decided according to Islamic law. One of the consequences of the Court of Appeal's judgment is that it is likely to affect all Kadhi's Court and High Court decisions in which

159 N Chome, "From Islamic reform to Muslim activism: The evolution of an Islamist ideology in Kenya” (2019) 118/472 African Affairs 531 at 535.

160 Č Nestorović, Islamic Marketing: Understanding the Socio-Economic, Cultural, and Politico-Legal Environment (2016, Springer) at 243.

161 MC Ricklefs, Islamisation and Its Opponents in Java: A Political, Social, Cultural and Religious History, c. 1930 to the Present (2012, NUS Press) at 284.

162 G Fealy and S White, Expressing Islam: Religious Life and Politics in Indonesia (2008, ISEASYusof Ishak Institute) at 164.

163 R Pringle, Understanding Islam in Indonesia: Politics and Diversity (2010, University of Hawai'i Press) at 138.

164 See also, In re Estate of Ramadhani Wambi Tirimisi (Deceased) [2020] eKLR.

165 Mustaq Alimohamed v Mohamed Iqbal Mohamed \& 2 others [2020] eKLR, para 21. 
these courts have found that non-Muslims cannot inherit from their Muslim parents or husbands. These decisions could easily be challenged. ${ }^{166}$ However, even Muslims have a right not to subject themselves to the jurisdiction of the Kadhi's Court, and in that case their dispute will be resolved by the High Court but based on Muslim law. ${ }^{167}$

It has been mentioned above that the Kadhi's Court and the High Court have held that under Islamic law, a child born out of wedlock cannot inherit from his father. This, as the Court of Appeal held, has a negative impact on the rights of the children. It appears that in order to ameliorate this impact, the Kadhi's Court, before the Court of Appeal decision discussed above, had come up with an exception - the issue of a compulsory will. In In re Estate of IOI (Deceased) ${ }^{168}$ the issue before the Kadhi's Court was whether a child born in a marriage that did not comply with Islamic law had a right to inherit from his deceased father. The child's mother submitted before the Court that she was married to the deceased under "customary law and not Islamic law" and that the child was born in that marriage before they divorced. She added that the deceased used to pay for the child's maintenance and school fees. ${ }^{169}$ The Court observed that the evidence before it showed that the child "was not born in a legal wedlock solemnised under Islamic law". ${ }^{170}$ The Court explained the conditions that have to be in place before a child can inherit from his Muslim father, and also referred to some of the High Court decisions to the effect that a child born out of wedlock cannot inherit from his father. ${ }^{171}$ The Court added that "[t]he deceased should have provided for him through a will. Muslims are allowed to bequeath up to a third of their estates to non heirs."172 The Court held further that since the deceased did not bequeath anything to the child, it was ready to explore the possibility of a "compulsory will". The question for the Court to decide was whether Islamic law allowed it to make a compulsory will "where a person who ought to have" made a will "did not make a will". ${ }^{173}$ It highlighted the fact that there were differences of opinion amongst Islamic scholars on this issue, with some arguing that a court can make such a will and others advancing the opposite argument. The Court quoted one of the Islamic authors who argued that:

166 See, for example, Omar Galana Hiribae v Alice Adhiambo Alucho [2017] eKLR (in which the Kadhi's Court held that the children who were born in a customary marriage between their deceased father and their Christian mother did not have a right to inherit from their father's estate).

167 Saifudean Mohamedali Noorbhai v Shehnaz Abdehusein Adamji, above at note 120 at 5.

168 In re Estate of IOI (Deceased), above at note 56.

169 Id, para 4.

170 Id, para 6.

171 Id, paras 7-13.

172 Id, para 14.

173 Id, para 15. 
"It is obligatory for every Muslim to make a bequeath to take care of his close relatives who are not entitled to inherit because of difference in faith, rules exclusion or simply they are not entitled to inherit him/her. He should provide for him through bequeath whatever he wishes, there is no limit to that. If he does not, the executor or heirs must provide for those relatives [from the estate]." ${ }^{174}$

The Court added that although the above view was of a minority of scholars, it could be relied on "when the need arises". ${ }^{175}$ Against that background, and quoting the Quran (chapter 4, verse 8), the Court held that:

"The court has discretion to apply the concept of compulsory will on a case to case basis according to the merit of the case to take care of the vulnerable relatives of the deceased not covered by bequeath or intestate succession. Islam directs heirs and executors to consider the poor relatives during distribution of estates." 176

The Court concluded that the child:

"[I]s not entitled to an inheritance share of the estate having been born out of legal wedlock. However he is a biological child of the deceased who used to care for him and is poor and needy. The heirs should give something in kindness. If they do not, the court, in my view, has discretion to apply, which I hereby do, the concept of compulsory will, in favour of the applicant to the extent of $20 \%$ of the deceased's proceeds in the bank and death gratuity with his employer." 177

There are at least two challenges with the Court's ruling. First, the Court highlighted the fact that the concept of a compulsory will was championed by a minority of Muslim scholars. This means that some Kadhis may not be supportive of the Court's approach. Secondly, the Court does not explain the reason behind allocating the share of 20 per cent to the child. Without a formula or guidelines that could be applied consistently, some people may become disgruntled over any percentage determined by the Court. This is likely to lead to conflicting decisions on this issue, depending on the school of thought followed by the Kadhi presiding over the matter, and could contribute to the challenge of fatwa shopping. Notwithstanding those challenges, the concept of a compulsory will could be invoked to address the thorny issue of children born out of wedlock - whether they are Muslims or not - and their right to inherit from their fathers. This approach would be more

174 Id, para 16.

175 Id, para 17.

176 Id, paras $17-18$.

177 Id, para 19. 
advantageous than that adopted by the Court of Appeal when it held that in such a case the Succession Act is applicable. First, it will be in line with the Constitution as it will protect the rights of the children as emphasized by the Court of Appeal. Secondly, it will ensure that the High Court does not apply the Law of Succession Act in such cases. And finally, it will not erode the jurisdiction of the Kadhi's Court in cases of this nature.

\section{The formula used to distribute the estate}

Another important question is whether the formula used in Islamic law to distribute the property of the deceased discriminates against women and is therefore unconstitutional. In In re Estate of Mohamed Kinango Kitonyo (Deceased) the protestors opposed "the distribution of the estate of the deceased on the ground that it is discriminatory on the basis of gender and therefore unconstitutional". ${ }^{178}$ The Court referred to articles 27 and 24(4) of the Constitution to hold that the right to equality is not absolute and therefore the formula is not unconstitutional. ${ }^{179}$ Five years before the High Court's judgment, the Kadhi's Court had explained the rationale behind the Islamic law rule that a man inherits twice the share of a woman. In In re Estate of Ramadhan Hassan (Deceased) the Kadhi's Court held that:

"[G]iven the Quranic specification it appears that male siblings inherit double the amount inherited by his sister but there is one vital justification on variations. The amount inherited by the sister is a net amount added to her wealth - this is a consequence of the rule of maintenance under Islamic law; A woman has exclusive right of disposal over her property whether she inherits it or earns it. She has no financial obligation/liability of maintaining even her children. The husband is bound to maintain her and her children however considerable her wealth may be. The amount inherited by a brother is a gross amount from which he will have to deduct the expenses of supporting the various women, elderly men and children in the family. Thus the share given to a man is in proportion to his responsibilities and not due to any superiority over the female." 180

Hence, the formula has to be viewed broadly and its purpose understood.

\section{Muslims and freedom of testation}

The Constitution of Kenya provides for every person's rights to acquire and own property. ${ }^{181}$ However, it does not provide for the right of a person to dispose of property. This does not mean that such a right does not exist. Thus, section 5(1) of the Succession Act provides that “... every person who is of

178 In re Estate of Mohamed Kinango Kitonyo (Deceased), above at note 97, para 7.

179 Id, paras 8-9.

180 In re Estate of Ramadhan Hassan (Deceased), above at note 36 at 8.

181 Art 40(1). 
sound mind and not a minor may dispose of all or any of his free property by will, and may thereby make any disposition by reference to any secular or religious law that he chooses". Kenyan courts have emphasized that section 5 provides for the freedom of testation. ${ }^{182}$ Although in SKHS $v$ SSNS ${ }^{183}$ the Court of Appeal did not find it necessary to address the issue of a whether a Muslim can make a valid secular will, it is argued that because section 5 of the Law of Succession Act does not form Part VII of the Act which is applicable to Muslims, a Muslim has to make a will that complies with Islamic law. If a Muslim makes a secular will, that will is invalid. In simple terms, as the High Court held in In Re Estate of James Karanja Alias James Kioi (Deceased), much as a person has freedom of testation, this freedom is not absolute and the court has to give effect to the wishes of the testator "unless it is prevented by some rule of law from doing so". ${ }^{184}$ In the case of a deceased Muslim's estate, section 2(3) of the Succession Act read with the relevant principles of Islamic law limits the testator's freedom of testation by requiring it not to transgress the boundaries of Islamic law. The Kadhi's Court has made it very clear that the Law of Succession Act does not fully comply with Muslim law and that Muslims should ensure that their estates are distributed according to Islamic law. ${ }^{185}$ Therefore, according to the law as it stands today in Kenya, a Muslim cannot make a valid secular will.

\section{CONCLUSION}

The author has dealt with the jurisprudence from Kenyan Courts on the issues of marriage and inheritance in the context of Islamic law and human rights. The author has discussed, inter alia, the conditions which have to be met for a Muslim marriage to be valid, the principles governing inheritance and the human rights issues arising out of these principles. It has been argued further that the Court of Appeal's decision in CKC \& another (Suing through their mother and next friend JWN) $v$ ANC, in which it held that a child born out wedlock could inherit from his/her Muslim father, was partly wrongly decided. This is so because it conflates the issue of the jurisdiction of the Kadhi's Court with the application of the Succession Act to the estate of a deceased Muslim. The author also argues that although the Law of Succession Act and international human rights instruments provide for the right of testation, Kenyan law does not allow Muslims to make valid secular wills.

\section{CONFLICTS OF INTEREST}

None

182 See, for example, In re Estate of Kibe Kihaguru Muhoho (Deceased) [2015] eKLR, para 17; In Re Estate of Wangoi Mutonga (Deceased) [2014] eKLR at 3.

183 SKHS $v$ SSNS, above at note 10.

184 In Re Estate of James Karanja Alias James Kioi (Deceased) [2014] eKLR, para 7.

185 In re Estate of Omari Hiribae Omari (Deceased), above at note 98 at 2. 